\title{
The Swiss Debt Brake - Ten Years On
}

In response to the rapid growth of public indebtedness during the 1990s, Switzerland enacted a constitutional budget restriction in 2003: the Swiss Debt Brake. Aimed at balancing the federal budget over the cycle the fiscal rule appears to have left its mark: At the debt brake's tenth anniversary, Switzerland's fiscal position has improved considerably. Several other countries have also implemented fiscal rules, but with mixed success. What lessons are there to be learned from these experiences?

To discuss this timely question, the Swiss Federal Finance Administration, the Swiss Society of Economics and Statistics, the Study Center Gerzensee and the University of Lucerne organised a conference in Gerzensee in November 2012. Academics and practitioners from Switzerland and abroad evaluated the theoretical case for fiscal institutions as well as their empirical track record and discussed proposals for improvements.

In addition to a welcome address by Eveline Widmer-Schlumpf, president of the Swiss Confederation, as well as policy panels with Hansjörg Blöchliger, George Kopits, Joakim Sonnegård, Peter Siegenthaler, Jan-Egbert Sturm and Guido Tabellini, the conference featured nine sessions. This special issue of the Swiss Journal of Economics and Statistics collects eight papers that were presented in those sessions.

The first paper by Tobias Beljean and Alain Geier provides an overview of the Swiss Debt Brake and describes the rule's introduction and its enforcement since 2003. The authors argue that the debt brake did not only lead to a substantial reduction in nominal debt but also modified the budget process by forcing policy makers to focus on overall fiscal policy objectives. Beljean and Geier also point out that the rule's simplicity and transparency contributed to its success and that there is no indication that the debt brake undermined countercyclical fiscal policy measures or worsened the accuracy of the budgeting process as measured by deviations between budgets and outcomes.

The second paper is a note by Peter Siegenthaler, director of the Swiss Federal Finance Administration in charge of implementing and applying the debt brake

a We are grateful to Fritz Zurbrügg and Gebhard Kirchgässner for their support in organizing the conference as well as to Gabriela Rychener and Corinne Conti Ambühl for their administrative support. 
in the years after 2003. Siegenthaler points to an important role of democratic legitimacy as well as public awareness and support in enforcing the fiscal rule. He argues that public support was particularly strengthened by the fact that the debt brake was introduced by popular vote. Siegenthaler also notes, however, that soaring social security spending might challenge this public support in the future.

Gebhard Kirchgässner looks in his paper at fiscal institutions at the sub-federal level in Switzerland. He argues that fiscal referenda and cantonal debt breaks play a prominent role in balancing the budgets, and that both institutions seem to matter for fiscal performance especially in economically weak cantons with limited revenue potential.

Carlo Cottarelli's paper discusses fiscal sustainability in Europe and makes a case for European Fiscal Union. Cottarelli argues that "more Europe" as well as tighter constraints on national fiscal policies is needed to overcome fiscal imbalances in the Euro area and to avoid that Monetary Union is put at risk. He also points to the role of risk sharing and labor market reform.

The paper by Ugo Panizza and Andrea Presbitero addresses the important question whether high public indebtedness slows down economic growth. Surveying recent literature on the link between debt and growth in advanced economies the authors report that many papers have found a negative correlation. Nevertheless, Panizza and Presbitero remain sceptical as to whether the available evidence provides support for a causal interpretation of the correlation and they offer suggestions for future research.

The remaining four papers discuss the merits of alternative fiscal institutions. Jakob de Haan, Niels Gilbert, Jeroen Hessel and Silvie Verkaart argue in favour of a major overhaul of European institutions. They propose a more centralized and independent enforcement of the European Stability and Growth Pact and in the long run, envision a fully independent budgetary authority with the means to enforce European budgetary rules. Once such an independent authority were in place, the authors argue, all public debt could be financed by issuing centrally backed Eurobonds provided that member states were no longer allowed to independently tap financial markets.

Barry Anderson's paper summarizes some lessons he learnt during his time in office as acting director of the US Congressional Budget Office (CBO). He argues that a central factor contributing to CBO's success has been the personality of its first director. Emphasizing the implications for Independent Fiscal Institutions (IFIs) Anderson concludes that "[h]aving a head who is simultaneously a forceful advocate for the agency but also primarily a low-key technician who avoids the limelight seems to be the most important factor in determining an IFI's future success". 
Torben Andersen's paper focuses on intermediate targets for fiscal policy and the experience of the Swedish fiscal policy council. Consistent with the view that personalities matter, Anderson discusses how intermediate targets for fiscal policy should be set and which role fiscal councils may play in strengthening political accountability and thus ultimately, credibility. With Sweden's consolidation process in the 1990s as well as its contemporary fiscal institutions and public finances widely commended the lessons learnt in Sweden might usefully guide countries currently undergoing difficult consolidation processes.

The last paper by Lars Feld discusses Germany's debt brake rule from 2009 and its implementation. The German rule shows important similarities with the rule adopted in Switzerland and requires budgets at the federal level and the level of individual states to be almost balanced over the cycle. While this design does promise to contribute to sustainable public finances only the future will show whether it actually delivers.

Dirk Niepelt

Christoph Schaltegger 